\title{
Stimulating Students' Argumentation using Drawing - based Modeling on The Concept of Ecosystem
}

\author{
E N Sumarni, A Widodo, and R Solihat ${ }^{1}$ \\ Biology Department of Graduate Program, Universitas Pendidikan Indonesia \\ Jl. Dr. Setiabudi No. 229, Bandung 40154, INDONESIA \\ E-mail : ensumarni@student.upi.edu
}

\begin{abstract}
Drawing - based modeling as learning approach, it allows students to create models based on drawing which help them to run a simulation. Students can use drawing-based modeling to learn a pair of interacting population known as predato-prey system while they usually conducted practicum using diagram of organisms. This study was to explore students' argumentation and students' understanding on the concept of the ecosystem. The study was conducted quasi experimental using the matching - only post-test - only control group design. The participants consist of 60 grade 10 senior high school students in Subang, West Java. They are placed into two groups, 30 students in the experimental group and 30 students in the control group. Data was collected through argumentation test and selected response test for assessing students' understanding. Students' argumentation were analyzed using Toulmin's argumentation pattern and statistical analysis. The result showed there is no significant difference between the experimental group and the control group for students' argumentation. Most of the students are predominantly at level 2 . But the coherency of arguments of the experimental group is more coherent than the control group. It means that the students in experimental group can make logical claim and supported by the correct and relevant grounds (data, warrant, and backing). The result of students' understanding showed there is a significant mean score between the experimental group and the control group whether 72.33 for the experimental group and 62.13 for the control group
\end{abstract}

Keywords: students' argumentation, drawing-based modeling, ecosystem

\section{Introduction}

Learning of 21 st-century skills are based on 4cs; critical thinking, communication, collaboration, and creativity. To answer the challenges of 21 st-century skills, Indonesia has been applied Curriculum 2013 which is emphasizes on the scientific process and reasoning. Learning on curriculum 2013 is based on "scientific approach" model that allows the students to find evidence and to reason [1]. Critical thinking skills developed along with building skills of argumentation [2]. Critical thinking and communication reflect many current developments in the teaching and learning of argumentation. The argument was processed which used by someone to analyze information on a topic and then results of the analysis was communicated to others [3]. Thus the using of argumentation in science learning was part of the development of higher order thinking skills [4].

Research on students' argumentation in science lesson showed that most students' argumentation skills were relatively immature in that most students were at the level 2 (of five levels) while only a small proportion of the students developed coherent 
arguments [1]. In line with the study in senior high school, students' argumentation is still in a simple statement without any support of evidence and reason. The students and teachers' discussion and interaction activities are less intensive. The results are indicating that the student has not been trained to argue [5].

To stimulate students' argumentation and students' understanding of the concept of ecosystem especially on the topic predator - prey system, drawing - based modeling can be used as learning approach. We usually conducted practicum using the diagram of organisms which compose food webs. In this study, we used drawing - based modeling using computer program simsketch as a modeling tool to create models and run into simulation [6].

\section{Methods}

\subsection{Research design}

This aim of the study was to explore students' argumentation and students' understanding the concept of the ecosystem using drawing - based modeling and diagram of organisms. The design was conducted quasi - experimental using the matching - only post-test - only control group design [7]. The participants in this study were 60 grade 10 senior high school students in Subang, West Java. They are placed into the experimental group and the control group, 30 students in the experimental group and 30 students in the control group. The students in experimental group using drawing - based modeling and the students in control group using a diagram of organisms that composes the food webs.

\subsection{Instruments}

Argumentation test consists of six questions focused on predator - prey system the concept that uses model and diagram while the selected response test consists of fifteen questions focused on students' understanding on the concept of the ecosystem.

\subsection{Implementation}

For the first time, the students in the experimental group are introduced how to use a drawing based modeling tool using an online computer program called simsketch with emphasis on the working of the tool. Because simsketch can only be accessed online and cannot be saved, that is why we used other application program that is 4video screen capture to save students' activity. Students drew models of organisms that compose food webs and run into a simulation. The students in control group organized the diagram of organisms that compose food webs.

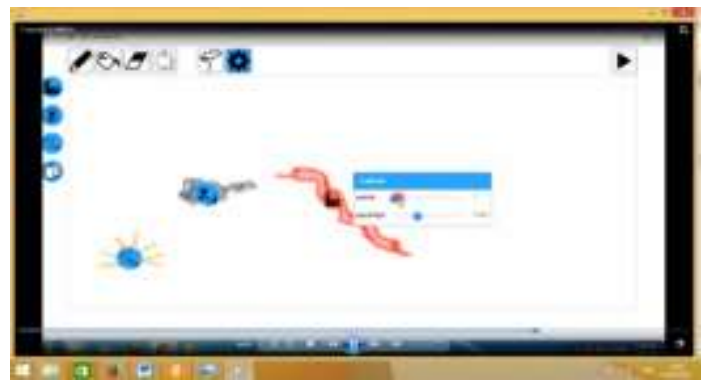

Figure 1. Students' result in experimental group 


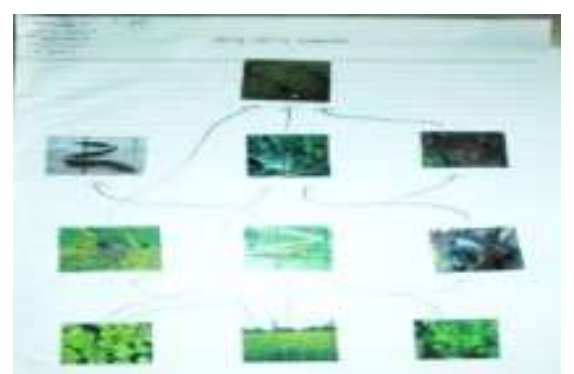

Figure 2. Students' result in control group Data analysis

The level of students' argument was analyzed using a modified rubric based on Toulmin's frame work [8].

Table 1. Level of students' argument

\begin{tabular}{|c|c|c|}
\hline Level & Description & Example \\
\hline 1 & Present a claim only. & I am going to use pesticide (claim). \\
\hline 2 & $\begin{array}{l}\text { Present a claim and data and/or } \\
\text { warrant. }\end{array}$ & $\begin{array}{l}\text { I am going to use pesticide (claim) because } \\
\text { pesticide contains chemicals that will kill the } \\
\text { insects (data), so that the number of the pests } \\
\text { will decrease (warrant). }\end{array}$ \\
\hline 3 & $\begin{array}{l}\text { Present claim, data, warrant, and } \\
\text { backing/ qualifier/ rebuttal. }\end{array}$ & $\begin{array}{l}\text { I am going to use pesticide (claim), but I will } \\
\text { choose only natural pesticide (qualifier) } \\
\text { because pesticide contains chemicals that kill } \\
\text { pests (data) The number of the pests will } \\
\text { decrease (warrant). }\end{array}$ \\
\hline 4 & $\begin{array}{l}\text { Presents all components of } \\
\text { argumentations: claim, data, } \\
\text { warrant, backing, qualifier, and } \\
\text { rebuttal. }\end{array}$ & $\begin{array}{l}\text { I am going to use pesticide (claim), but I will } \\
\text { choose only natural pesticide (qualifier) It is } \\
\text { because pesticide contains chemicals that kill } \\
\text { pests (data) The number of the pests will } \\
\text { decrease (warrant) because pesticides kills } \\
\text { pests (backing). } \\
\text { I am going to use pesticide (claim) although I } \\
\text { know that pesticide is not good for the } \\
\text { environment (rebuttal) It is better to use } \\
\text { natural pesticide (qualifier) because pesticide } \\
\text { contains chemicals that kill pests (data) The } \\
\text { number of the pests will decrease (warrant) } \\
\text { because pesticides kill pests (backing). }\end{array}$ \\
\hline
\end{tabular}

The students' responses were analyzed based on the coherence and comprehensiveness of the components of their answers [1]. 
Table 2. Level of coherency and relationship between components in the examination scripts

\begin{tabular}{ll}
\hline Category & Description of the rubric \\
\hline Higher & Claim is logic and is supported by a correct and relevant \\
grounds (data, warrant, backing) & Example: \\
& To fights rice pests we can use controlled insecticide and \\
& natural predators of the insect Insecticide works by affecting \\
& the physiology of the insects while predatorsprey the insects \\
Reasonable & Claim is logically make sense and is supported by a sound \\
coherency & ground. \\
& Example: \\
& I am going to use insecticide because it will kill pests \\
& Claim logically make sense but no supporting grounds or the \\
Limited & ground is incorrect or irrelevant \\
coherency & Claim doesn't logically make sense and provides no \\
& supporting grounds \\
& Example: \\
& Building a wooden fence around the rice field to protect rice \\
field from pests.
\end{tabular}

Students' understanding of the concept of ecosystem was analyzed using statistical analysis.

\section{Result and Discussion}

The result in figure 3 shows in general, the level of students' argumentation had similar patterns in both the experimental and the control group. Most of the students are predominantly at level 2 . It means that students can make a claim and present some data or warrant, but a few of them can make a rebuttal. The students in the experimental group can reach level 3 and level 4 slightly higher than students in the control group, but it did not significant difference.

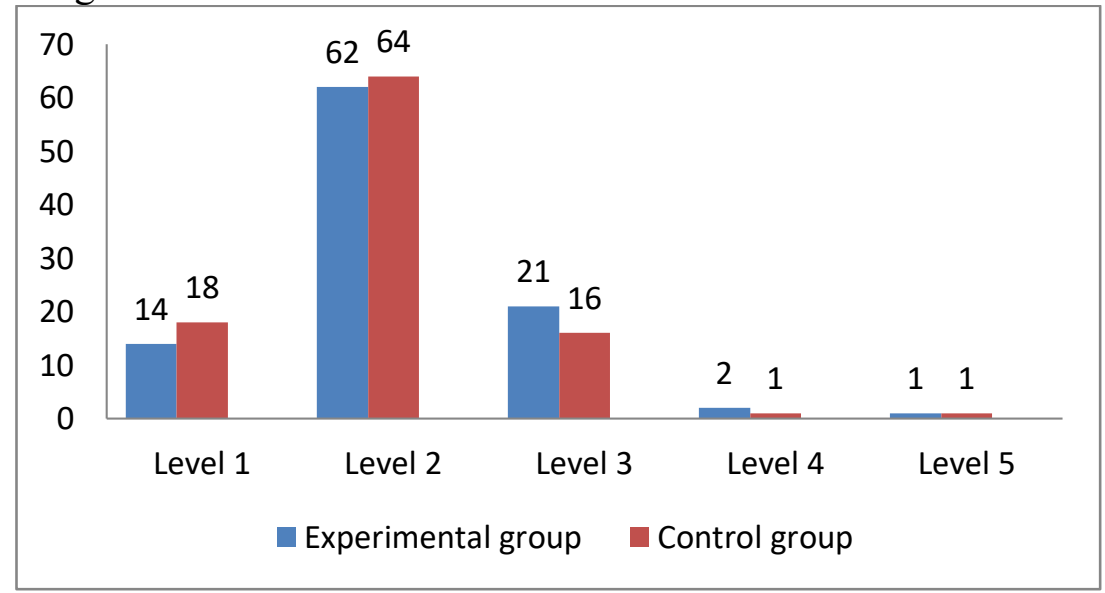

Figure 3. Percentage of students' argumentation 
This finding agreed with the previous research that students' argumentation are predominantly at level 2 [1]. The development of students' argumentation relies on the teaching - learning process. There are many factors effecting to students' argumentation; teachers' question, discussion, practicum, class management, students' conceptual understanding, and school activities program [9]. To enhance students' argumentation skills, the teachers should use appropriate learning strategies. Argument driven inquiry is possible to implement as a strategy to facilitate students' learning using argumentation [10].

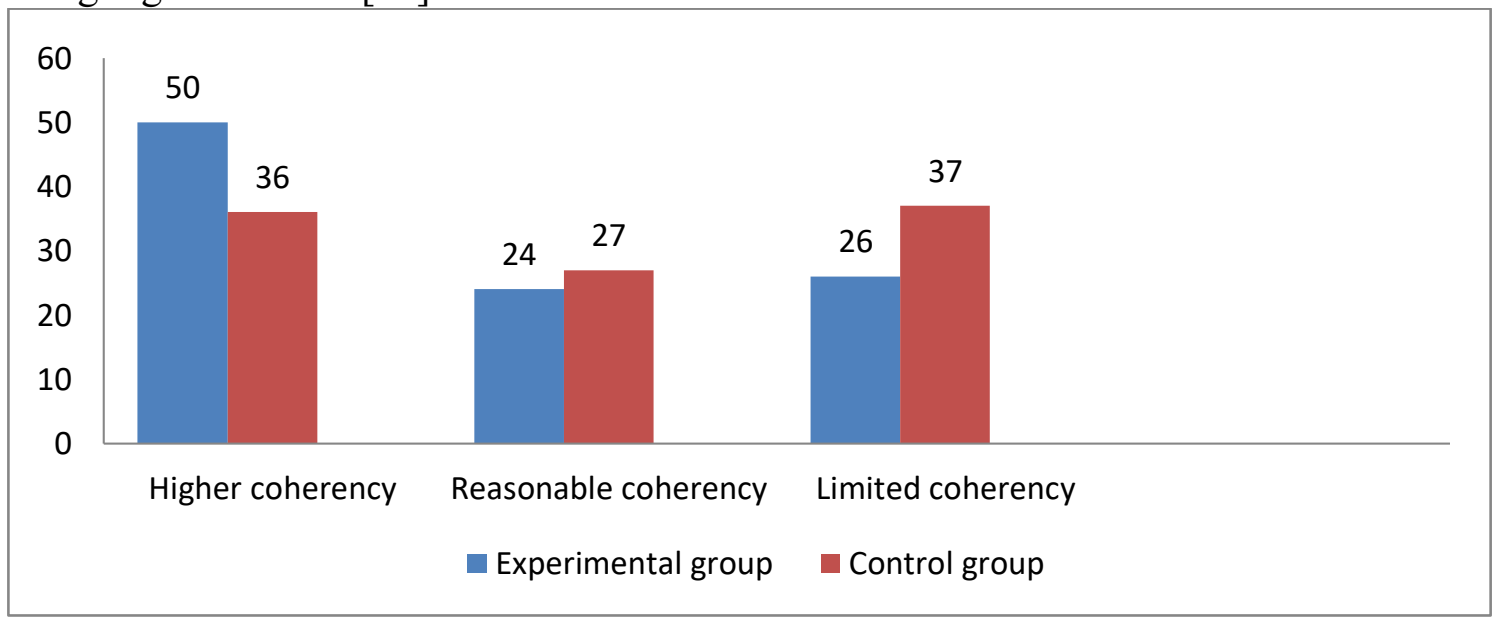

Figure 4. Percentage coherence of students' argumentation

Figure 4 shows that students in the experimental group tend to be able to formulate more coherence arguments compare to control group. The results indicate that drawing - based modeling can stimulate students to provide more detail explanation and supporting evidence for their answer. The students can make logical claim and supported by a correct and relevant grounds (data, warrant, backing), because drawing based modeling can stimulate scientific reasoning and allows students explain the concept more deeply [11].

The mean score of students' understanding on the concept of ecosystem shows significant difference between experimental group and control group. The mean score of the experimental group 72.33 and the control group 62.13. The analyze included normality test which was used to analyse whether the score is normal or has normal distribution is shown in table 3.

Table 3. One Sample Kolmogorov - Smirnov Test

\begin{tabular}{llccc}
\hline \multicolumn{1}{c}{ Group } & N & Mean & Std. Deviation & Sig.(2-tailed) \\
\hline Experimental & 30 & 72.33 & 13.61 & 0.215 \\
Control & 30 & 62.13 & 10.63 & 0.161 \\
\hline
\end{tabular}

The value of $\alpha$ for the post test of the experimental group is 0.215 and the value of the post test in the control group is 0,161 which are slightly higher than 0.05 . It means that the scores of the test are normal and they can also be analyzed by using the t-test. The result is shown in table 4. 
Table 4. The result of independent t-test

\begin{tabular}{lccc}
\hline \multicolumn{1}{c}{ Group } & T & Df & Sig.(2-tailed) \\
\hline Experimental & -3.234 & 58 & 0.02 \\
Control & -3.234 & 55 & 0.02 \\
\hline
\end{tabular}

Table 4 shows the value of sig (two tailed) which is 0.02 is lower than 0.05 . It means that there was significant difference between the experimental group and the control group. The result indicates that drawing - based modeling can stimulate students' understanding on the concept of the ecosystem. Because there is a process that students can reason through the models and can run into a simulation. It encourages students' understanding the concept. Drawing is an active process and increase students' motivation because students are used to operate computer well. Based on previous study drawing - based modeling can be used to stimulate scientific reasoning [11] and may contribute to higher levels of scientific reasoning and this activity enables students to revise their spontaneous thoughts into more scientific concepts [12].

\section{Conclusion}

Teaching and learning of argumentation have to foster in science education. Arguments are only one kind of communication and reflect of critical thinking because to argue students should make a claim, and supported by evidence and by the reasoning or inference that connect the evidence to the claim. Furthermore students should make rebuttals from socioscientific issues or opposition [3]. A higher number of rebuttals indicate that the students learn to look issues from different perspectives [1]. The students' have to train to argue because the students are not used to being trained to argue in the learning.

Drawing - based modeling can be implemented to stimulate students' argumentation, but it has to support by inquiry strategy. Based on the previous research, teaching strategy which can be implemented to improve students' argumentation skill in science lesson is argument driven inquiry [10]. Or guided inquiry course [13]. Drawing-based modeling can stimulate students' understanding, there was an active process and enables students to revise their spontaneous thoughts [12].

\section{References}

[1] Widodo, A., Waldrip, B \& Herawati, D. 2016 Indonesian Journal of Science Education 5199

[2] Minarti \& Hayat. 2015 International Conference on Mathematics Science and Education 85

[3] Inch, E. S., Warnick, B \& Endres, D. 2006 Critical Thinking and Communication. USA: Pearson

[4] Erduran, S., \& Maria, PJ., 2008 Argumentation in Science Education, London: Springer

[5] Pritasari, Dwiastuti, \& Sajidan. 2015 Indonesian Journal of Science Education 4(2) 158

[6] Bollen, L., \& van Joolingen, W. R 2013 IEEE Transactions on Learning Technologies 11939

[7] Fraenkel, Wallen, \& Hyun. 2012 How to Design and Evaluate Research in 
Education. New York: The McGraw-Hill Companies

[8] Choi, A., Notebaert, A.,Diaz, J., \& Hand, B. 2010 Research in Science Education 40(2) 149

[9] Herawati, Desti. 2015. Penalaran Ilmiah (Scientific Reasoning) Siswa Sekolah Berorientasi Lingkungan dan Sekolah Multinational. (Tesis, Universitas Pendidikan Indonesia)

[10] Sampson, V. \& Gleim, L 2009 American Biology Teacher 71(8) 465

[11] Heijnes, Dewi. 2015 Research Project (45 ECTS) of Science Education and Communication. Freudenthal Institute for Science and Mathematics Education, Utrecht University

[12] Schouten, J.H.Y. 2016 Research Project (45 ECTS) of Science Education and Communication. Freudenthal Institute for Science and Mathematics Education, Utrecht University

[13] Acar, O \& Patton, B.R. 2012 Procedia - Social and Behavioral Sciences 464756 